\title{
THE MILK PRODUCTION OF REINDEER COWS AND THE SHARE OF MILK IN THE GROWTH OF REINDEER CALVES
}

\author{
Mikko Varo and Hannu Varo \\ Department of Animal Breeding, University of Helsinki
}

Received May 22, 1970

\begin{abstract}
The milk quantities obtained from the reindeer cows in the present study are probably, due to technical difficulties in the milking, lower than the actual values. For this reason the figures on the milk producing ability, and the connection between the milk yield and other characteristics of the cow or its calf, are bound to be uncertain. The general composition of reindeer milk is in fair agreement with results reported by other researchers (Tables 1,4 and 5).

Individual differences in the milk producing ability could clearly be detected. The correlations between the milk quantity and the constituents were usually not significant. The association between the dam's spring weight and the protein percentage was significant $\left(\mathrm{r}=-0.47^{* *}\right)$.

The range of the calves' weights at birth was to a large degree mainteined during the entire period of growth (Table 9). The weight and growth of the calves was clearly dependent on the weight or on the size of the dam. The results obtained did not indicate any connection between the milk production characteristics of the dams and the growth of the calves (Tables 11 and 12). The spring weight of the dam has a more decisive influence on the growth of the calf than the birth weight of the latter.

The results obtained seem to indicate that in the breeding for growth capacity, selection on the basis of the weight or size of the dams os of conclusive importance. In spite of the individual variations existing in the milk producing ability of reindeer cows, the importance of the quantity and composition of the milk seems to be covered by the genetically determined growth factors. As the size of reindeer can be determined more easily than the weight, the combined measure, (body length + chest girth), seems tobe a more suitable basis for evaluation.
\end{abstract}

Since 1965 the reindeer breeding studies, started on the initial of the Reindeer Keeper's Association in 1962 at Askankangas in Puolanka (VARO 1964), has been continued at the Reindeer Experimental Region Kaamanen in Inari. During the summer 1967, in the period June 1st to Sept. 15th, the subject of study was the milk production ability of reindeer cows and the possibly existing variation between dams in this respect, as well as the influence of these factors on the development of the reindeer calves.

During the experiment the weather conditions were relatively good. Precipitation and temperature were below average, which apparently resulted in a decreased number of mosquitoes and gadflies. Work among the reindeer was thus rather easy. 
In order to catch the reindeer, small pasture fences had to be erected. When fencing new pasture areas one sometimes encountered such difficult conditions of terrain that cloth fences had to be used. This was also why the entire herd escaped in the middle of July and was lost for over a week. Later, the reindeer were herded in a $4 \mathrm{~km}^{2}$ wide area, situated $10 \mathrm{~km}$ from the experimental region. The construction of a small fence, however, took so long that the herd again scattered. In spite of continuous efforts barely one half of the experimental animals could eventually be caught.

This misfortune naturally seriously affected the reliability of the results. The observed quantities of milk should be regarded with great caution also because the reindeer cows were not used to such close contact with human beings as was required in the milking process. Greatly depended on the nature of cow whether the animal did or did not give milk.

\section{Review of the literature}

The literature on the milk yields of reindeer is very limited. The Norwegian research worker SKJENNEBERg (1965) notes that the amount produced varies between 100 and $750 \mathrm{~g}$ per day, the most favourable lactation period being July-August. On the other hand, information on the average composition of reindeer milk is plentiful. Table 1 shows the values, as percentages, given by different researchers. The values are reported either as averages or as changes during the lactation period.

Table 1. The composition (\%) of reindeer milk according to various researchers.

\begin{tabular}{lrrrrr}
\hline & \multicolumn{1}{c}{ Fat } & \multicolumn{1}{c}{ Protein } & Lactose & Ash & Solids \\
\hline & & & & & \\
WERENSKIOLD 1895 & $14.5-19.7$ & $10.3-11.5$ & $3.0-2.6$ & $1.5-1.4$ & $29.8-35.7$ \\
BARTHEL \& BERGMAN 1914 & $20.2-28.3$ & $9.7-11.2$ & $2.2-2.8$ & & \\
DAVIES 1936 & 17.1 & 10.4 & 2.1 & 1.5 & 31.8 \\
BRODY 1945 & 22.5 & 10.3 & 2.5 & 1.4 & \\
SILVER 1961 & $8.0-18.0$ & $8.8-11.5$ & $3.8-2.2$ & & \\
AsCHAFFENBURG et. al. 1962 & $9.2-16.9$ & $7.2-11.5$ & $3.9-2.8$ & & $22.2-33.1$ \\
BERGE 1963 & $15.1-24.7$ & $8.7-11.5$ & & & \\
SKJENNEBERG 1965 & 20 & 10 & 2.8 & 1.5 &
\end{tabular}

DRURi \& MATUSChev (1963) present averages on the weight development of calves (Tables 2 and 3). The breed in question is considerably larger than our own.

According to the present writer, R.M. VARO (1964), the average birth weight of calves, born in spring 1963, was $5.80 \mathrm{~kg}$, the heaviest calf weighing 7.45 and the smallest one $4.70 \mathrm{~kg}$. A small but statistically significant difference between the sexes was noted. The calves by cows of different ages did not significantly differ in weight. 
Table 2. The average weight $(\mathrm{kg})$ development of reindeer calves by month

(DruRi \& Matuschev 1965).

\begin{tabular}{lrr}
\hline Age & Weight & Growth \\
\hline Birth weight & 6.7 & \\
1 month & 18.0 & 11.3 \\
2 months & 30.0 & 12.0 \\
3 " & 42.6 & 12.6 \\
$4 "$ & 51.6 & 9.0 \\
5 " & 58.8 & 6.4
\end{tabular}

Table 3. The average weight $(\mathrm{kg})$ development of reindeer calves and that of the smallest and largest one (kg) (DruRi \& Matuschev 1963).

\begin{tabular}{lccc}
\hline Age & Average & Smallest & Largest \\
\hline Birth weight & 6.4 & & \\
1 month & 16.1 & 10.9 & 9.2 \\
2 months & 26.7 & 16.8 & 22.4 \\
3 " & 39.5 & 25.2 & 34.4 \\
4 " & 49.6 & 30.8 & 50.5 \\
\end{tabular}

Own studies

$\mathrm{M}$ a terial a nd met hods. The reindeer cows of the experiment were mainly born in 1963 (VARo 1964). Some other reindeer, also younger ones, were likewise included. In the spring 1967 a total of 33 calves were born, of these two died immediately after the calving and two dams with calves disappeared. Thus the material consisted of 29 calf-cow pairs. Later, during the course of the experiment, three calves had to be delivered to the State Game Research Institute and one calf was lost in an accident.

Originally the intention was to do $3-4$ milking rounds by milking the dams in their calving order. In this way the milk samples would have been obtained after approximately the same period after calving. This plan could, however, not be fully realized because the reindeer managed to escape. The collection of samples and the weighing of the animals was done by two students, H. Kullberg and H. Varo.

The cows to be milked, two animals each day, were in the evening separated from their calves and kept in a $2 \times 3 \mathrm{~m}$ enclosure. The animals were given water, moistened lichen and Peura-fodder. The milking took place the following morning and evening. The calves were weighed during the same day. The milk quantities obtained were combined and from the mixture a sample of approx. $80 \mathrm{ml}$. was taken and put into a plastic flask containig formalin. The samples were kept in a nearby cold brook and were weekly sent for analysis to the Department of Dairy Science of Helsinki University. With the aid of Peurafodder the reindeer were easily caught, but the milking often took quite long. Occasionally a cow had to be released because it had damaged its developing horns. 


\section{Results}

The milk production of the cows. The milk quantities obtained varied between 47 and $206 \mathrm{ml}$ per milking day. In order to make the values comparable they were corrected to correspond to the amounts of milk obtained 30 and 60 days after calving. The new values obtained in this vay varied between 54 and $207 \mathrm{ml}$ and between 47 and $202 \mathrm{ml}$ for samples collected 30 and 60 days, respectively, since the calving. The corresponding averages were 99.8 and $96.9 \mathrm{ml}$. For reasons given above connected with the milking, it is probable that the milk quantities obtained are lower than the real ones of reindeer cows.

The general composition of reindeer milk in the present material is given in Tables 4 and 5 (Luhtala, Rautiainen \& Antila 1968). Table 5 shows that the solids and fat percentages steadily increase during the experimental period, whereas the protein percentage is at its lowest in the middle of the period.

Table 4. The general composition of reindeer milk in percentage (LuHTALA et al.)

\begin{tabular}{lcc}
\hline Characteristic & Average & Range \\
\hline Solids & 39.09 & $30.20-49.74$ \\
Fat & 20.53 & $12.68-30.03$ \\
Protein & 12.78 & $6.88-15.46$ \\
Lactose & 3.08 & $2.77-3.23$ \\
Ash & 2.12 & $2.02-2.29$
\end{tabular}

Table 5. Changes in the average composition of reindeer milk during the experimental period in percentage (Luhtala et al.)

\begin{tabular}{ccccc}
\hline $\begin{array}{c}\text { Time of milking } \\
\text { (days from calving) }\end{array}$ & Samples & Solids & Fat & Protein \\
\hline $25-30$ & 5 & 27.18 & 10.79 & 10.60 \\
$30-40$ & 14 & 27.85 & 13.12 & 10.16 \\
$40-50$ & 8 & 31.52 & 16.33 & 9.82 \\
$50-60$ & 8 & 32.04 & 16.05 & 9.77 \\
$80-100$ & 7 & 40.91 & 21.65 & 13.85 \\
$100-120$ & 5 & 38.09 & 19.58 & 13.05
\end{tabular}

In order to detect the possible individual differences in the milk production ability of reindeer cows an analysis of variance was carried out. As the milk samples were obtained at different stages of the nursing period, the measure of production capacity used was the milk yield deviation of the individual cow from the general average curve. The F-values and the coefficients of repeatability are collected in Table 6. 
Table 6. The milk production ability of reindeer cows. F-values and repeatabilities.

\begin{tabular}{lccc}
\hline Characteristic & F & Significance & Repeatability \\
\hline Milk quantity & 2.43 & $*$ & 0.37 \\
Fat \% & 4.15 & $* *$ & 0.57 \\
Protein \% & 4.20 & $* *$ & 0.60 \\
Solids \% & 4.30 & $* *$ & 0.60
\end{tabular}

Table 7 shows all correlations between weight in spring, milk yield and milk composition. It appears that the contents of fat and protein are independent. The correlations between milk yield and composition were not significant and were always negative. Likewise the correlations between the cow's weight in spring and the other caracteristics were in most cases nonsignificant. Only the correlation for the protein content was significant, $\mathrm{r}=-0.47(\mathrm{P}<0.01)$.

The weight development of the calves. The calves included in the experiment were born between May 6th and 23rd. The birth weight was, on an average, $5.63 \mathrm{~kg}$, the standard deviation being $0.74 \mathrm{~kg}$. The lightest calf weighed 4.2 and the heaviest $7.5 \mathrm{~kg}$. Female calves weighed, on an average, 5.28 and male calves 5.93 .

Table 7. Correlations between milk quantity, milk constituents and the weight of reindeer cows in spring.

\begin{tabular}{lcccc}
\hline Characteristic & Milk quant. & Fat $\%$ & Prot. $\%$ & Solids \% \\
\hline & & & & \\
1 month after calving & -0.054 & -0.048 & $-0.469^{*}$ & -0.078 \\
Weight in spring & & -0.027 & -0.221 & -0.141 \\
Milk quantity & & 0.003 & 0.865 \\
Fat \% & & & 0.236 \\
Protein \% & & & \\
& & & & \\
2 months after calving & -0.040 & -0.142 & $-0.467 *$ & -0.171 \\
Weight in spring & & -0.075 & -0.174 & -0.188 \\
Milk quantity & & 0.076 & 0.918 \\
Fat \% & & & 0.048 \\
Protein \% & & &
\end{tabular}

Table 8 shows the development of the weights of the calves during the summer period. The weight of 3 month old calves in a few cases had to be evaluated on the basis of their earlier development and the overall average growth capacity.

The individual differences with regard to the weight development of the calves were detected by means of a similar analysis of variance as in the matter of the milk production of the cows. The calculations were thus done on the basis of the deviations of the weights from the means at different ages. 
Table 8. The development of the weight $(\mathrm{kg})$ of the calves.

\begin{tabular}{lrrrrrr}
\hline & Male & $\begin{array}{l}\text { Weight } \\
\text { Female }\end{array}$ & Averages & Male & $\begin{array}{r}\text { Growth } \\
\text { Female }\end{array}$ & Averages \\
\hline Birth weight & & & & & & \\
1 month & 5.93 & 5.28 & 5.63 & & & \\
2 months & 16.24 & 14.26 & 15.35 & 10.31 & 8.98 & 9.72 \\
$3 \quad$ " & 25.97 & 22.52 & 24.42 & 9.73 & 8.26 & 9.07 \\
& 35.13 & 29.99 & 32.83 & 9.16 & 7.47 & 8.40
\end{tabular}

Table 9 shows that the ranges in weight at birth have to a considerable extent been mainteined during the experiment, although less so in the males than the females.

When evaluating the dependence of the growth of the calves on the weight of the dams in spring, the weight differences caused by sex have been levelled. As all dams were weighed at the same time, April 24-25, 1967, the weights in spring are not altogether comparable on account of the differences in the stages of pregnancy. Moreover, the closeness of the weighing date to the calving may have increased the correlations. The correlations calculated using the weight of the dams in autumn (1967) probably give a more accurate picture of the association. Table 10 shows the dependence of the weight of the calves on the weights of the dams in spring and autumn, on the dam's body length, chest girth and on the two latter measures combined. Taking into account the inaccuracy of the spring weights of the cows when evaluating the dam, the combined measure seems quite suitable. The magnitude of the coefficients indicates that in addition to the genes also the embryonic period and the ability of the dams to take care of the calves may have had its effect on the correlations.

Table 9. The development of the weight of the calves. F-values and repeatabilities.

\begin{tabular}{llll}
\hline Sex & F & Significance & Repeatability \\
\hline & & & \\
Male & 2.44 & $*$ & 0.33 \\
Female & 5.30 & $* * *$ & 0.61 \\
Averages & 2.84 & $* * *$ & 0.40
\end{tabular}

Table 10. Correlations between the weight development of calves and the weights and measurements of dams.

\begin{tabular}{|c|c|c|c|c|c|c|c|}
\hline \multirow[b]{2}{*}{ Dam } & \multicolumn{4}{|c|}{ Weight } & \multicolumn{3}{|c|}{ Growth } \\
\hline & Birth & 1 month & 2 months & 3 months & 1month & $1-2$ months & $2-3$ months \\
\hline Spring weight & 0.42 & 0.62 & 0.69 & 0.66 & 0.63 & 0.53 & 0.28 \\
\hline Autumn weight & 0.40 & 0.60 & 0.60 & 0.55 & 0.53 & 0.44 & 0.19 \\
\hline Body length & 0.37 & 0.44 & 0.56 & 0.68 & 0.35 & 0.56 & 0.57 \\
\hline Chest girth & 0.35 & 0.62 & 0.66 & 0.63 & 0.59 & 0.55 & 0.27 \\
\hline $\begin{array}{l}\text { Body length }+ \\
\text { chest girth }\end{array}$ & 0.39 & 0.58 & 0.66 & 0.71 & 0.51 & 0.60 & 0.46 \\
\hline
\end{tabular}


Table 11 shows the correlations between different milk characteristics of the dam and the growth rate of the calf. The large negative values are probably due to the fact that the correlations between the weights of the calves and the spring weights of the dams are high and positive (Table 10), while those between the weights of the dams and the milk traits are negative (Table 7). Moreover, it should be noted that already when the calves were less than one month old they consumed other nutrients beside milk, among other things Peura-fodder, which is rich in protein and trace elements. If the influence of the spring weight of the dams is eliminated from the above correlations, the coefficients get higher and become positive, with the exception of the correlations concerning the protein percentage. The values are, however, not significant, as the $5 \%$ level is at 0.37 (Table 12).

Table 11. Correlations between the milk characteristics and the weight development of calves.

\begin{tabular}{|c|c|c|c|c|c|c|c|}
\hline \multirow[b]{2}{*}{ Dam } & \multicolumn{4}{|c|}{ Weight } & \multicolumn{3}{|c|}{ Growth } \\
\hline & Birth & 1 month & 2 months & 3 months & 1 month & $1-2$ months & $2-3$ month \\
\hline \multicolumn{8}{|c|}{1 month after calving } \\
\hline Milk quantity & -0.03 & -0.03 & -0.20 & -0.30 & -0.01 & -0.36 & -0.35 \\
\hline Fat $\%$ & 0.03 & 0.15 & 0.16 & 0.04 & 0.18 & 0.13 & -0.20 \\
\hline Protein \% & -0.00 & -0.39 & -0.35 & -0.32 & -0.53 & -0.19 & -0.12 \\
\hline Solids $\%$ & 0.08 & 0.11 & 0.13 & 0.02 & 0.10 & 0.12 & -0.20 \\
\hline \multicolumn{8}{|c|}{2 months after calving } \\
\hline Milk quantity & -0.06 & -0.03 & -0.20 & -0.31 & 0.00 & -0.37 & -0.36 \\
\hline Fat $\%$ & 0.09 & 0.10 & 0.05 & -0.05 & 0.07 & -0.02 & -0.26 \\
\hline Protein $\%$ & 0.04 & -0.38 & -0.34 & -0.28 & -0.54 & -0.20 & -0.04 \\
\hline Solids $\%$ & 0.09 & 0.04 & 0.04 & -0.03 & 0.00 & 0.20 & -0.13 \\
\hline
\end{tabular}

Table 12. Correlations between milk characteristics and the weight development of calves (Influence of weight of dam eliminated).

\begin{tabular}{ccc}
\hline Dam & Weight, 1 month & Growth, 1 month \\
\hline
\end{tabular}

1 month after calving

$\begin{array}{lrr}\text { Milk quantity } & 0.001 & 0.028 \\ \text { Fat \% } & 0.231 & 0.273 \\ \text { Protein \% } & -0.142 & -0.341 \\ \text { Solids \% } & 0.204 & 0.194\end{array}$

2 months after calving

$\begin{array}{lrr}\text { Milk quantity } & -0.125 & 0.242 \\ \text { Fat \% } & 0.204 & 0.161 \\ \text { Protein \% } & -0.025 & -0.156 \\ \text { Solids \% } & 0.221 & 0.161\end{array}$

When evaluating the correlations concerning the weights and growth of the calves (Table 13), it may be noted that the influence of the birth weight on the later weights all the time decreases. The influence of the birth weight on the growth is negligible. 
Table 13. Correlations between the weight and growth characteristics of calves.

$\begin{array}{cc}\text { Weight } & \text { Growth } \\ \text { Birth } 1 \text { month } 2 \text { months } 3 \text { months } & 0-1 \text { month } 0-2 \text { months } 1-2 \text { months } 0-3 \text { months }\end{array}$

$\begin{array}{llll}\text { Weight } & & & \\ 1 \text { month } & 0.69 & & \\ 2 \text { months } & 0.54 & 0.91 & \\ 3 \quad \text { N } & 0.41 & 0.71 & 0.92\end{array}$

Growth

\begin{tabular}{|c|c|c|c|c|c|c|c|c|c|}
\hline $0-1$ & lonth & 0.25 & 0.87 & 0.85 & 0.68 & & & & \\
\hline $0-2$ & onths & 0.26 & 0.79 & 0.95 & 0.91 & 0.89 & & & \\
\hline $1-2$ & $n$ & 0.21 & 0.55 & 0.85 & 0.93 & 0.60 & 0.90 & & \\
\hline $0-3$ & $"$ & 0.23 & 0.62 & 0.87 & 0.98 & 0.68 & 0.92 & 0.95 & \\
\hline $2-3$ & $"-$ & -0.04 & 0.01 & 0.32 & 0.67 & 0.03 & 0.38 & 0.63 & 0.70 \\
\hline
\end{tabular}

\title{
REFERENCES
}

Aschaffenburg, R., Gregory, Margaret, E., Kon, S. K., Rowland, S. J. \& Thompson, S. Y. 1962. The composition of the milk of the reindeer. J. Dairy Res. 29: 325-328.

Barthel, C. \& Bergman, A. M. 1914. Z. Nahrgenussm. 26: 238.

BERGE, S. 1963. Nye analyser av reinsmjølk. Tidsskr. norske landbr. 70, 3: 27-34.

Brody, S. 1945. Bionergetics and growth. New York. Ref. Berge 1963.

Davies, W. L. 1936. The chemistry of milk. London. Ref. Berge 1963.

Druri, I. V. \& Matuschev, E. O. 1965. Olenevodstvo. 243 p. Moskva.

Luhtala, A., Rautiannen, A. \& Antila, M. 1968. Die Zusammensetzung der finnischen Rentiermilch. S. Kemistilehti B 41: 6-9.

PoIJÄRvı, I. 1945. Jäkäläruokinnalla olevien porojen jäkälänkulutus syksystä kevääseen. Valt. Maatal. koet. Tied. 205.

Silver, H. 1961. J. Wildlife Mgmt, 25, 66.

SkJenneberg, S. 1965. Rein og Reindrift.

VAro, R. M. 1964. Tutkimuksia poron jalostusmahdollisuuksista. Summary: Investigations on the possibilities of reindeer breeding. Ann. Agric. Fenn. 3: 296-310.

Werenskiold, F. 1895. Rensdyrmelk. Tidskr. norske landbr. 2: 372-375.

\section{SELOSTUS}

\section{VAATIMIEN MAIDONTUOTANTOKYVYSTÄ JA MAIDON OSUUDESTA VASOJEN KASVUSSA}

\author{
Mikko Varo ja Hannu Varo
}

\section{Kotieläinten jalostustieteen laitos, Helsingin Yliopisto}

Puolangan Askankankaalla 1962 Paliskuntain Yhdistyksen toimesta aloitettua poronjalostustutkimusta (VARO 1964) on jatkettu vuodesta 1965 lähtien Kaamasen porokoealueella Inarissa. Vuoden 1967 kesällä, 1.6.-15.9. välisenä aikana oli tutkimuksen kohteena vaatimien maidontuotantokyky, ja sen vaikutus vasojen kehitykseen.

Sääolosuhteet kesän aikana olivat suhteellisen hyvät. Sademäärät ja lämpötilat olivat tavallista alhaisemmat, mikä ilmeisesti vaikutti sääskien ja kurmupaarmojen vähyyteen. Työskentely porojen parissa oli siten melko vaivatonta.

Porojen kiinnisaamiseksi oli käytettävä pieniä kangasaitauksia. Uusia laidunmaita aidattaessa jouduttiin joskus niin vaikeisiin maasto-olosuhteisiin, että oli pakko käyttää pelkkiä kangasaitoja. Tästä oli- 
kin seurauksena, että heinäkuun puolivälissä koko tokka karkasi ja oli kateissa toista viikkoa. Myöhemmin porot saatiin kootuksi $10 \mathrm{~km}$ :n päässä tutkimusasemalta olevalle n. $4 \mathrm{~km}^{2}$ :n laajuiselle alueelle. Pikkuaitauksen rakentaminen kesti kuitenkin niin kauan, että lauma oli ehtinyt jo hajaantua. Jatkuvista yrityksistä huolimatta saatiin koe-eläimistä kiinni vain vajaa puolet.

Edellämainitulla epäonnella oli tietenkin huomattava haittavaikutus tulosten luotettavuuteen. Saatuihin maitomääriin on suhtauduttava sangen varovasti senkin vuoksi, että vaatimet eivät olleet tottuneet ihmisen kanssa niin läheiseen kosketukseen, jota lypsytoimitus edellyttää. Tällöin riippuu paljon eläimen luonteesta, antaako se maitoa vai ei.

$\mathrm{Katsaus} \mathrm{kirjallisuuteen.} \mathrm{Poron} \mathrm{maitomääristä} \mathrm{on} \mathrm{kirjallisuudessa} \mathrm{mainintoja} \mathrm{sangen}$ niukasti. Norjalainen SKJENNEBERg (1965) mainitsee, että maitomäärä vaihtelee 100-750 g:aan päivässä, parhaan tuotoskauden ollessa heinä-elokuussa. Poronmaidon keskimääräisestä koostumuksesta on runsaasti tietoja. Taulukossa 1 nähdään eri tutkijoiden ilmoittamat arvot prosentteina. Ne on ilmaistu joko keskiarvoina tai muutoksina lypsykauden aikana.

Vasojen painonkehityksestä mainitsevat DrUdi \& MATUschev (1963) keskiarvotietoja, jotka ilmenevät taulukoista 2 ja 3 . Kyseessä on rotu, joka on meikäläistä poroa tuntuvasti kookkaampi.

Kirjoittajan (R. M. VARO 1964) mukaan koeaineistossa keväällä 1963 syntyneiden vasojen syntymäpaino oli keskimäärin $5.80 \mathrm{~kg}$, suurimman vasan painaessa 7.45 ja pienimmän $4.70 \mathrm{~kg}$. Sukupuolten välillä oli havaittavissa pieni, mutta tilastollisesti merkitsevä ero. Eri-ikäisten vaatimien vasat eivät eronneet painoiltaan merkitsevästi toisistaan.

O m a t t u t kim u ks e t. Kokeessa mukana olleet vaatimet olivat pääasiassa vuonna 1963 syntyneitä. Joukossa oli muutamia muitakin poroja, myös nuorempia. Keväällä 1967 syntyi 33 vasaa, mutta niistä kuoli kaksi heti syntymän jälkeen, ja lisäksi kaksi emää vasoineen katosi. Aineisto käsitti siten kaikenkaikkiaan 29 vasavaadin-paria. Myöhemmin kokeen aikana jouduttiin Riistantutkimuslaitokselle luovuttamaan kolme vasaa, ja yksi vasa kuoli tapaturmaisesti.

Alunperin oli tarkoituksena suorittaa 3-4 lypsykierrosta siten, että emät olisi lypsetty vasomisjärjestyksessä. Näin olisi maitonäytteet saatu suunnilleen yhtä pitkän ajan kuluttua vasomisesta. Tästä jouduttiin kuitenkin tinkimään porojen karkaamisen takia. Näytteiden keruun suorittivat ylioppilaat $\mathrm{H}$. Kullberg ja $\mathrm{H}$. Varo.

Lypsettävät vaatimet, joita oli kaksi kunakin päivänä, erotettiin illalla vasoistaan n. $2 \times 3 \mathrm{~m}: \mathrm{n}$ suuruiseen aitaukseen. Eläimille annettiin vettä, kostutettua jäkälää ja Peura-rehua. Lypsy tapahtui seuraavana aamuna ja iltana. Vasat punnittiin saman päivän aikana. Saadut maitosaaliit yhdistettiin ja seoksesta otettiin formaliinia sisältävään muovipulloon n. $80 \mathrm{ml}: n$ näyte. Maitonäytteet säilytettiin läheisessä kylmässä purossa ja lähetettiin viikottain Helsingin Yliopiston maitotalouslaitokselle analysoitaviksi. Peura-rehun avulla porot saatiin helposti kiinni, mutta itse lypsy venyi usein hyvinkin pitkäksi. Silloin tällöin oli vaadin päästettävä vapaaksi sen loukattua kẹhittyvät sarvensa.

V a a ti m i e n m a id on t u o t a n t o. Saadut maitomäärät vaihtelivat 47-206 ml:aan lypsypäivää kohti. Jotta arvot olisivat vertailukelpoisia, ne on korjattu vastaamaan maitomääriä $30 \mathrm{ja} 60 \mathrm{vrk}$ vasomisen jälkeen. Tällä tavoin saadut uudet arvot vaihtelivat $54-207 \mathrm{ml} 30 \mathrm{vrk}$ ja $47-202 \mathrm{ml} 60 \mathrm{vrk}$ vasomisen jälkeen. Vastaavat keskiarvot olivat 99.8 ja $96.9 \mathrm{ml}$. Saadut maitotuotokset lienevät kuitenkin vaatimien tuottamia todellisia maitomääriä pienemmät aiemmin mainituista lypsyä vaikeuttaneista syistä.

Poronmaidon yleiskoostumus nyt tutkitussa aineistossa käy ilmi taulukoista 4 ja 5 (LUHTALA, RAUTIAINEN \& ANTILA 1968). Taulukosta 5 nähdään, että kuiva-aine- ja rasvaprosentti kohoavat tasaisesti koekauden aikana, kun taas valkuaisprosentti on alimmillaan kauden keskivaiheilla.

Vaatimien maidontuotantokyvyssä mahdollisesti ilmeneviä yksilöllisiä eroja tutkittiin varianssianalyysillä. Koska koelypsyt oli tehty imetyskauden eri vaiheissa, käytettiin tuotantokyvyn mittana vaatimien maitotuotoksien poikkeamia yleisestä keskiarvokäyrästä. F-arvot ja toistumiskertoimet on koottu taulukkoon 6.

Kaikki kevätpainot, maidon määrän ja sen koostumuslukujen väliset korrelaatiot on esitetty taulukossa 7. Siitä nähdään mm., että rasva- ja valkuaispitoisuudet eivät ole toisistaan riippuvia. Maidon määrän ja sen koostumuslukujen väliset korrelaatiot olivat aina negatiivisia, mutta eivät merkitseviä. Vaatimien kevätpainon ja maidon koostumuslukujen väliset negatiiviset korrelaatiot eivät useimmiten myöskään olleet merkitseviä. Ainoastaan valkuaispitoisuudesta saatu kerroin, $r=-0.47$, oli merkitsevä $(\mathrm{P}<0.01)$.

Vasojen painonkehitys. Kokeessa mukana olleet vasat syntyivät $6.5-23.5$ välisenä 
aikana. Syntymäpainojen keskiarvo oli $5.63 \mathrm{~kg}$ ja hajonta $0.74 \mathrm{~kg}$. Pienin vasa painoi 4.2 ja suurin $7.5 \mathrm{~kg}$. Naarasvasat painoivat keskimäärin 5.28 ja urosvasat $5.93 \mathrm{~kg}$. Vasojen painojen kehitystä kesän aikana kuvaa taulukko 8. Vasojen painoja kolmen kuukauden iässä on jouduttu eräissä tapauksissa arvioimaan niiden oman aikaisemman kehityksen ja yleisen keskimääräisen kehityksen perusteella.

Vasojen painonkehityksen yksilölliset erot on saatu esille samanlaisella varianssianalyysillä kuin vaatimien maidontuotantokykyä tutkittaessa. Laskuissa on siis käytetty yksilön poikkeamia ikäkauden keskiarvosta. Taulukko 9 osoittaa, että painojärjestys, joka oli syntyessä, on suuressa määrin säilynyt kokeen aikana, joskin heikommin uros- kuin naarasvasoilla.

Tarkasteltaessa vasojen kasvun riippuvuutta emien kevätpainosta on vasojen sukupuolesta johtuvat painoerot tasoitettu. Koska emät punnittiin samaan aikaan (24.—25. 4. 1967), eivät kevätpainot ole täysin vertailukelpoisia sikiöiden eri-ikäisyyden takia. Punnitus- ja vasomisajankohdan läheisyys on siten voinut suurentaa korrelaatiota. Oikeamman kuvan antanevat emien syyspainosta (1967) lasketut korrelaatiot. Taulukossa 10 on esitetty vasojen painon ja kasvun riippuvuus emien kevätpainosta ja seuraavan syksyn syyspainosta, vartalon pituudesta, rinnan ympäryksestä sekä kahden viimeksimainitun summana muodostetusta yhteismitasta. Kun otetaan huomioon vaatimien kevätpainojen epävarmuus emän arvostelussa, näyttää yhteismitan käyttö varsin tarkoituksenmukaiselta. Kertoimien suuruus viittaa siihen, että perintötekijöiden ohella myös sikiökausi ja emän kyky huolehtia vasastaan ovat saattaneet vaikuttaa korrelaatioiden muodostumiseen.

Emän maidontuotanto-ominaisuuksien ja vasan painonkehityksen väliset korrelaatiokertoimet ilmenevät taulukosta 11. Eräiden korrelaatiokertoimien suuret negatiiviset arvot johtunevat siitä, että emien painon ja vasojen painon väliset korrelaatiot olivat suuria ja positiivisia (taulukko 10), kun taas emien painon ja niiden maidontuotanto-ominaisuuksien väliset korrelaatiot olivat negatiivisia (taulukko 7). Lisäksi on otettava huomioon, että vasat söivät jo alle kuukauden ikäisinä maidon ohella muutakin ravintoa, muun muassa Peura-rehua, joka sisältää runsaasti valkuaista ja hivenaineita. Jos po. korrelaatioista poistetaan emien kevätpainon vaikutus, kertoimet suurenevat ja muuttuvat positiivisiksi lukuunottamatta valkuaisprosenttia koskevia korrelaatioita. Merkitseviä arvot eivät kuitenkaan ole, sillä raja, P - 0.05, on 0.37 (taulukko 12).

Vasojen eri painojen ja kasvulukujen keskinäisiä korrelaatioita (taulukko 13) tarkasteltaessa voidaan huomata, että vasan syntymäpainon vaikutus myöhempään kehitykseen koekautena pienenee jatkuvasti. Kasvuun ei syntymäpainolla ole merkitsevää vaikutusta.

Tuloste n t a r k a t e l u ja pä ä e l mät. Vaatimilta saadut maitomäärät lienevät lypsyteknillisistä vaikeuksista johtuen todellisia määriä pienemmät. Siitä syystä sekä yksilöllisen maidontuotankyvyn arviointi että maitotuotosten yhteys yksilön omiin tai sen vasan muihin piirteisiin jää epävarmaksi. Maidon yleiskoostumus on vastannut suurin piirtein muiden tutkijain aikaisemmin saamia tuloksia (talukko 1,4 ja 5).

Vaatimien maidontuotantokyvyssä näyttää olevan yksilöllisiä eroja (taulukko 6). Maidon määrän ja koostumuslukujen välillä ei yleensä ollut merkitsevää korrelaatiota. Emän kevätpainon ja maidon valkuaisprosentin välillä oli merkitsevä negatiivinen korrelaatio $\left(r=-0.47^{* *}\right)$. Voiko tähän olla syynä vuodenaikojen mukaan voimakkaasti vaihteleva yli- ja aliruokinta? PoIJÄrven (1945) mukaan kookas poro kuluttaa talvisaikaan suhteellisesti enemmän kudostensa rakennusaineita kuin pienikokoinen. Myös Kaamasen koe-eläinten suhteelliset painonvähennykset olivat isokokoisilla poroilla 99 prosentin merkitsevyydellä suuremmat kuin pienikokoisilla. Toisaalta poron talvisin syömä ravinto ei juuri lainkaan sisällä sulavaa raakavalkuaista (PoIJÄRvı 1945). Viittaako tämä siihen, että suuremmat porot ovat alkukesästä valkuaisen suhteen huonommassa ravitsemustilassa kuin pienemmät, mikä heijastuisi myös maidon valkuaispitoisuudessa? Ongelma lienee lisätutkimusten arvoinen.

Vasojen syntymäpainojen mukainen painojärjestys säilyi saman suuntaisena koko tutkimuskauden ajan. Vasojen painot ja kasvu riippuivat selvästi emän painosta tai koosta. Emän maidon määrällä tai koostumuksella ja vasan kasvulla ei näyttänyt olevan yhteyttä keskenään (taulukot 11 ja 12). Emän kevãtpainon vaikutus vasan kasvuun on voimakkaampi kuin tämän oman syntymäpainon.

Saadut tulokset osoittavat, että porojen kasvutaipumuksen jalostamisessa painoon tai kokoon perustuva valinta on ratkaiseva. Vaatimien maidontuotantokyvyn yksilöllisestä vaihtelusta huolimatta näyttää maidon määrän ja sen koostumuksen merkitys peittyvän perityn kasvutaipumuksen varjoon. Koska poron koon mittaus on helpommin suoritettavissa kuin punnitus, näyttää yhteismitta nytkin saatujen tulosten mukaan käyttökelpoisimmalta arvosteluperusteelta. 